\title{
New Thing? Gender and Sexuality in the Jazz Composers Guild
}

\author{
Benjamin Piekut
}

I

n October 1964 composer and trumpeter Bill Dixon produced a four-day festival of adventurous jazz and improvised music at the Cellar Café on New York's Upper West Side. Titled "The October Revolution in Jazz," the event was notable for the large number of musicians who performed, the sizeable audiences that attended, and the favorable press that ensued. ${ }^{1}$ Nightly panel discussions lent an academic air to the proceedings, with conversations touching on social, economic, and aesthetic concerns. Though the young musicians who were working with the innovations of Ornette Coleman and Cecil Taylor had been performing in coffeehouses and lofts for years, the October Revolution represented a formalization of sorts, an auspicious announcement of a loose, polystylistic movement known as the "New Thing."

In the weeks following this successful event, Dixon formed the Jazz Composers Guild, a musicians' cooperative that included some of the leading figures in the New York scene: Cecil Taylor, Sun Ra, Paul Bley, Archie Shepp, John Tchicai, Roswell Rudd, Burton Greene, Michael Mantler, Alan Silva, Jon Winter, and Carla Bley. ${ }^{3}$ One of the first significant attempts at self-determination by jazz musicians, the Guild sought to reorient the exploitative working conditions of the major clubs and record companies by withdrawing their labor from the market. Guild rules stated that any outside performance or recording opportunity had to be voted on by the collective, with the expectation that members would do their best to parlay individual opportunities into projects involving the whole group. In the meantime, the organization presented weekly concerts at the Cellar Café through the end of 1964, when they produced a second four-night festival called "Four Days in December," December 28 through 31. The concerts were held in Judson Hall on West 57th Street and, like the October Revolution, garnered significant press attention and large audiences. ${ }^{4}$

In January 1965, the Guild moved its base of operations to the studio of choreographer Edith Stephen, whose triangular space at Seventh Avenue and 11th Street was located above the Village Vanguard. Ensembles led by Guild 
members appeared there three times a week until the end of April, creating what Jacques Attali called "a parallel industry to produce and promote new music," before ultimately folding in a storm of infighting after only six months. ${ }^{5}$ It was a turbulent moment in the New York jazz underground, and the Guild was not the only force of organization and support. In March 1965 the writer and critic Amiri Baraka (then LeRoi Jones) founded the Black Arts Repertory Theatre and School in Harlem, where he hosted avant-garde jazz concerts and outdoor festivals that spring and summer. Sun Ra, Shepp, and Milford Graves (who was not a Guild member, but the drummer for Rudd and Tchicai's New York Art Quartet) all associated closely with Baraka during their time in the Guild. Meanwhile, attorney Bernard Stollman, who had founded ESP-Disk records in 1964, appeared at the October Revolution and offered to record every musician he heard. ${ }^{6}$ The New York Art Quartet and Paul Bley would both record for ESP in the fall of 1964, though the albums were not released until after the Guild's demise.

In such a rapidly shifting scene, alliances were quick to form and personal animosities abounded: between Dixon and Shepp, Sun Ra and Taylor, Ra and Carla Bley, Baraka and Greene, Carla Bley and Stollman. In particular, the rivalry between the Black Arts writers and the Guild was exacerbated by the animus shared by Dixon and Baraka, who had traded barbs in the jazz press and in person. ${ }^{7}$ In a review of Dixon and Shepp's second Savoy album, which featured the music of one composer per side, Baraka wrote, "The Shepp side contains the serious business." ${ }^{8}$ Nearly a year earlier, Dixon had written a long letter to Down Beat criticizing Baraka's inaccuracies in reporting, as well as his "turgid self-conscious 'in-group' superiority generally and rightly associated with pseudo-intellectuals." Stollman was also folded into this charged debate-while Baraka speculated in Down Beat whether ESP artists were getting paid as much as their producer, Guild-friendly critic and journalist Robert Levin excoriated Stollman as "a very typical current demonstration of the exploitation of the Negro jazz musicians by the white business man." 10

In this article I examine the ways in which patterns of gender and sexuality structured and inflected relationships and conflicts in New York's avant-garde jazz scene in the mid-1960s, particularly those relationships involving members of the Jazz Composers Guild. As much work in critical race and gender studies has made clear, social categories are often intertwined in complex ways, and I tug at this messy knot using Ruth Frankenberg's "trope-ical family," a set of stereotypes, themes, and deeply embedded narratives about four cardinal figures: White Man, White Woman, Man of Color, and Woman of Color. To write about one of these figures is to write about all of them, as each acquires 
its specific meanings in a larger ensemble of relationships conditioned by race, gender, sexuality, and class. Pulling at one strand, in other words, brings the whole mess with it.

I hope to show how gender provided a set of values and a vocabulary through which the hostility between Dixon and Baraka, in particular, could be enacted. Although it may be tempting to view the animus they shared as a simple matter of gossip, I contend that this label is itself a gendered (and sexualized) framing of jazz discourse, a judgment about what belongs in a scholarly treatment of jazz worlds. ${ }^{11}$ The conflict, however, had serious implications for how the field of avant-garde jazz took shape-imagine how differently things might have worked out, for example, had the Guild found a rent-free home at the Black Arts Repertory Theatre and School, where they could save money for future projects and perhaps learn more about acquiring foundation support. By reframing the conflict between Dixon and Baraka in the terms of gender analysis - and out of the feminized and devalued sphere of gossip-I am practicing what Sherrie Tucker calls "ear-training . . . to better listen for gender in the dissonances, silences, and negotiations of tricky changes at all levels of jazz studies." 12

As I argue below, the nationalism of the Black Arts Movement that informed Baraka's criticism in this period entailed a particular collection of relationships with white women, women of color, and white men, all marked by a certain sexual ambivalence. In particular, Cecil Taylor emerges as a key figure of this ambivalence, because his problematic sexuality disrupted the stability of the relationships Baraka aimed to establish. I also consider the experience of Carla Bley in the Guild, and how she and other women composers and musicians negotiated the social terrain of 1960s jazz. Attending to gender in this context affords the opportunity not only to examine the specificities of women's exclusion from mainstream and alternative forums of jazz life, but also to follow how gender framed the discourse of free jazz itself-men and women, insiders and outsiders alike.

Although the Guild was a short-lived institution local to New York City, its influence was widespread. This influence partially owed to the fact that, in the jazz worlds of the 1960s, a local conversation in New York City was far more than local, and indeed the debates that are the subject of this study extended to the pages of national magazines such as Down Beat, Sounds \& Fury, and Jazz, not to mention Melody Maker in the UK and Jazz Magazine in France. The Guild's (and Baraka's) status as inspiration and example can be detected in a number of cases: George E. Lewis notes that the Guild was a topic of discussion at one of the first organizational meetings of the Association for 
the Advancement of Creative Musicians in Chicago during the summer of $1965 ;{ }^{13}$ Carla Bley and Mantler used the knowledge gained from the Guild project to found the Jazz Composers Orchestra Association, one of the most important musician-run publishing and promoting organizations of the late 1960s and 1970s; Rudd recalls loaning his copy of the Guild's constitution to bassist Reggie Workman when the latter was organizing the Collective Black Artists in 1970; ${ }^{14}$ and Eric Drott recently detailed the great impact of Baraka's writings on a generation of jazz critics and intellectuals in France at the end of the 1960s. ${ }^{15}$ Furthermore, the themes of self-determination, collective struggle, Jim Crow, black nationalism, and musical encodings of race were not limited to the outlines of this particular story, but played out in a variety of ways in mainstream jazz discourse throughout the 1960s.

Black nationalism and its ideological variants entered the discourse of jazz much earlier than other African American styles. Although folk and gospel constituted the soundtrack on the front lines of the civil rights movement, it was jazz that attracted the attention of African American critics and intellectuals who wanted to articulate the discourse of black liberation to specific forms of expressive culture. Ingrid Monson observes that "the symbolic centrality of ... jazz in particular in the celebration of cultural pride was tied to the fact that jazz was an interracially and internationally recognized arena of black excellence- the domain of cultural leadership in which African Americans were the reigning cultural heroes." ${ }^{\prime 6}$ As scholars such as Tammy Kernodle and Brian Ward have demonstrated, rhythm-and-blues, rock'n' roll, and soul were much slower to articulate black nationalist themes than jazz was. ${ }^{17}$ For all of these reasons, jazz in general, and free jazz and the Guild in particular, are of paramount importance in assessing the place of these freedom discourses in African American music.

Writers on the Jazz Composers Guild — this one included-have found race to be the most perspicuous factor influencing the short existence of the organization. Indeed, racial discourse was a key mediator in the competition for leadership of the avant-garde, as well as within the Guild itself. Members of the interracial organization held a variety of views on integration, solidarity, and self-determination. While most of the African American members understood the organization as a project of black self-determination, the white musicians were more inclined to view it as a concert-producing body for avantgarde music that had no chance in the commercial marketplace. As Austrian trumpeter Mantler recalled, "I was interested in music. I had no interest in this being a political organization-black/white and stuff." ${ }^{18}$ If whites were often confused by or resistant to the attention being drawn to issues of race 
in Guild meetings, the black members regarded their white comrades with a certain distrust. Though not a member himself, drummer Graves had close personal and professional relationships with several Guild members. Referring to what he often heard in private, he comments, "I used to say to myself, 'I wonder if the white guys are talking about the black cats like the black cats are talking about the white guys when we're not with each other...' People didn't understand that there was suspicion of white people at the time." 19

Dixon's decision to include white musicians in the Guild brought criticism from Baraka and other intellectuals associated with the Black Arts Repertory Theatre and School. From the perspective of the Black Arts Movement, a radical separation from white society was needed to cultivate African American pride. Both organizations sought to present African American music in venues other than the commercial jazz clubs, but for somewhat different reasons. Dixon wanted control over the means of production and distribution for his music so that it might be presented in a high art, rather than entertainment, context. Baraka, along with other Black Arts writers such as Larry Neal and A. B. Spellman, was more concerned with the majority white audiences in the clubs, and instead wanted to enroll the black working classes in his vision of an authentic, African American music. Though Dixon criticized the Black Arts writers for what he saw as their misguided attempt at achieving racial purity, he told the journalist Taylor Castell in 1965, "I do agree with Jones about white America being totally unable to accept any kind of leadership from black Americans." ${ }^{20}$

The competition for leadership of the jazz avant-garde did not solely concern race; black nationalism also dictated appropriate behavior for men and women and prescribed desirable aesthetic qualities based on gendered codes of musical meaning. Scholars such as Eric Porter, Sherrie Tucker, David Ake, Krin Gabbard, Nicole Rustin, Ingrid Monson, and Monique Guillory have examined masculinity and its intersections with class, race, sexuality, and jazz. ${ }^{21}$ Ake, for example, points to the ability to play changes as a marker of masculinity in the bebop era, when the cutting contest was a common form of manly competition between virtuoso instrumentalists, and argues that Ornette Coleman's appearance in New York in 1959 destabilized this model of masculinity by doing away with the regular harmonic changes that underlay bop improvisations. As Ake argues, Coleman's "Lonely Woman" can be read as a site of fluid gender play, but the emerging free jazz movement the composer helped inaugurate was hardly one of enlightened masculinity. The qualities most admired in this music were volume, "raw" and extreme emotion, dominating tone, and virtuosic displays of hand and breath control. 
Baraka vividly expressed these values in his evocative description of Albert Ayler: "He had a sound, alone, unlike anyone else's. It tore through you, broad, jagged like something out of nature. Some critics said his sound was 'primitive.' Shit, it was before that! It was a big massive sound and wail. The crying, shouting moan of black spirituals and God music.... Yeh, the music. Feeling all that, it touching us and us touching it, gave us that strength, that kind of irrevocability we felt. Like the thunder or the lightning or the ocean storming and mounting, crushing whatever was in its path." ${ }^{22}$ Ekkehard Jost's commentary on Archie Shepp's pacing ("short, eruptive phrases") and tone also links credibility to emotionality, as when he writes of Shepp's "wide vibrato and a full — and slightly breathy — tone, a sound in which growl and shout effects do not appear extraneous, but rather serve to heighten emotion in a quite natural way." 23

Baraka and Spellman frequently criticized Dixon's playing, perhaps because the trumpeter's musical style avoided the tropes of dominant free jazz masculinity. Dixon's solo on Taylor's ;Conquistador!, to take one well-known example of his performance style, is a starkly minimal, inward exploration of plaintive melody and timbre on the instrument, containing few of the theatrical shrieks and grunts or acrobatic runs that were common in the playing of Ayler and Shepp — this is exactly why the musical statement is so shocking and memorable. ${ }^{24}$ Spellman wrote of Dixon's performance at the "Four Days in December": "It seems that every time I hear him he is overshadowed by most (in this case all) of the men in his band. His playing is unusually sparse for a trumpet player who leads, sparse in content, volume and length. $\mathrm{He}$ plays mostly long sustained notes deliberately placed just outside the chord, so quiet that you have to strain to hear. It sounded to me like he has to play this way because, as the musicians say, his chops are down: his lips are too soft because of lack of practice." ${ }^{25}$ In reading this, we are to understand that Dixon is a shrinking violet (he is overshadowed by the men in his band), that he is not a real leader (his playing is too sparse), that he is weak, and that he does not have the sense of duty or work ethic to practice (he is lazy). The description contrasts markedly with the same critic's view of Shepp's "hard-blowing quintet": "Shepp dominates this group. His style is hard and overpowering and, talented as they are, this group does not push him, though with a few months' rehearsal and working, most of these men will be able to challenge him."26

The break between Dixon and the Black Arts intellectuals was partially generational (Dixon was ten or more years older than Baraka, Shepp, Graves, Spellman, and Neal), and in the mid-1960s such a generational split was also 
inflected by invidious racial and gendered meanings. It is well known that moderate and old-guard institutions such as the NAACP and the SCLC pursued integration, while younger organizations such as SNCC transitioned to a more purposeful self-segregation from whites. ${ }^{27}$ The militancy of this latter impulse led predictably toward the assertion of a strong black masculinity that simultaneously positioned the older generation as soft and ingratiating, thereby equating integration with the uplift-minded middle classes, which, as Monson has argued, were associated in the postwar jazz landscape with moralizing black women and femininity in general. ${ }^{28}$ In my conversations with Dixon about the October Revolution and the Guild, he made it clear that he viewed the dialogues about race that occurred in both contexts as pedagogical. The majority-white audiences at the festival had little awareness of the levels of inequality that were endured by African American musicians, but "they could not say that after they finished four days of those panels [at the October Revolution]," he recalled. ${ }^{29}$ In the eyes of Dixon's younger colleagues, however, this concern with educating whites in the evils of racism appeared old-fashioned, futile, and even spineless, especially in a context already conditioned by the association of integration with obeisance and vulnerability.

In contrast to Dixon's patient education of whites, Baraka recalls that, by the end of 1964, he had acquired "the reputation of being a snarling, whitehating madman." ${ }^{\prime 0}$ The same could be said about Shepp, whose inclusion in the circle around Baraka was facilitated partly by his sound on the saxophone, but also by the political values he shared with the group. ${ }^{31}$ An eloquent spokesman for black radicalism, Shepp also reproduced the gender blind spots of the movement, as when he told an interviewer, "I'm merely suggesting that birth-control is the bogey-man as far as I'm concerned and it's a way of skirting around the real issues. After all, Bobby Kennedy can have 10 children and be damn well proud of it. That is the right of every man, to make as many children as he desires." 32

Although Shepp's comments constituted a response to the control of black reproduction historically and to perennial racist fears over black birth rates, this response also took the form of patriarchal control, indicating the degree to which black nationalist men based their liberation movement on a reactionary understanding of the family and black women's roles as mothers and caretakers. As Patricia Hill Collins writes, "Although Black cultural nationalism staunchly opposed racial oppression, it ironically incorporated dominant ideologies about White and Black gender roles into its domain assumptions." 33 She further notes that while black women became mothers of the nation, "black men serve as warriors in the revolution. As warriors, they 
maintain the right to sleep with, own, and in some cases rape the women of the alien nation, white women, while receiving praise for these actions." ${ }^{34}$ Indeed, Baraka, Shepp, Spellman, and others had white wives or girlfriends during these years, and these relationships at times were the source of some tension. Saxophonist Marzette Watts, who lived in the same Cooper Square building as Baraka and Shepp, recalled debating Malcolm X on occasion as a member of Baraka's activist group, the Organization of Young Men: "And when we'd get him in a corner, he'd always chase us out of Harlem by saying, 'That's fine, brother Watts, brother Jones, but you're downtown sleeping with those white women!'”35

Reflecting on her marriage to Baraka, an interracial partnership that was unraveling by the end of 1964 , Hettie Jones observes, "But this had been-at first—precisely his point, that a black man should be free as any man-to lead his life, to love one and/or attack another, at once. ${ }^{36}$ This view of black-white romance as a measure of freedom soon came under pressure from African American female activists such as the musician Abbey Lincoln, who wrote, "White female rejects and social misfits are flagrantly flaunted in our faces as the ultimate in feminine pulchritude. Our women are encouraged by our own men to strive to look like the white female image as much as possible." ${ }^{37}$ As Farah Jasmine Griffin explains, Lincoln's essay "Who Will Revere the Black Woman?" (1966) was a powerful defense of African American women's dignity and beauty at a time when black womanhood was severely marginalizedpassed over by black men chasing the ideal of white femininity, African American women were also blamed for the ills of the race by the controversial Moynihan report of 1965. Nonetheless, Lincoln's plea for respect stopped "just short of a black feminist statement. ... [W] [ile she does call for black women to organize ...., it is not a call for them to organize for their own social and political rights, but instead a call for them to organize in order to enlighten black men." ${ }^{38}$ Lincoln's commitment to a unified black nationalism meant supporting and obeying the strong African American male protector, and these patriarchal values suffused the Black Power movement. In the words of Wini Breines, 'man' and 'manhood' were often employed as equivalents for the achievement of personhood, respect, and dignity. The black males stood center stage, strong, proud, and furious, a crucial building block in the imagery of black nationalism. His rage anchored the movement." ${ }^{39}$

The occlusion of womanhood in this movement of black nationalism is never a full erasure, Fred Moten reminds us, but a displacement of sexual difference onto mother Africa, the natal moment of Africa-as-origin that is simultaneously the site of an impossible return. ${ }^{40}$ Difference within blackness 
functions not only ontologically_essentialized blackness is cut by sexual difference in the return to maternal Africa — but also historically, as Moten identifies the conditions of possibility for Baraka's 1965 turn to black nationalism in his early-1960s bohemian period in the East Village. Ingrid Monson describes the scene: "This hip subculture, comprising black Americans interested in Western artistic nonconformity and white Americans captivated by urban African American styles of music, dress, and speech, fashioned itself as a vanguard cultural force against the 'shoddy cornucopia of popular American culture."'\$1 Downtown bohemianism is nothing if not transgressive, and Moten centers the discussion on homoeroticism. He writes,

The limits of black arts are set by the rejection of a certain revolutionary embrace that is embedded in bohemianism.... There are questions here concerning decadence or deviance. The black arts are, in part, the cultural vehicle of return to a certain moral fundamentalism, one based on (the desire for) African tradition rather than white/bourgeois normativity. This is to say that they would enact a return to the former after having enacted the bohemian rejection of the latter. The embrace of the homoerotic is, here, an opening and not an $\operatorname{aim}^{42}$

In this milieu Baraka and his circle of black artists and intellectuals joined their white comrades in resisting bourgeois, white normativity, an opposition that Moten links with non-normative sexual practices: same-race homosexuality, interracial homosexuality, and interracial heterosexuality. ${ }^{43}$ These transgressive sexualities—particularly homosexuality—are recast as deviant by Baraka when he moves uptown in 1965. (Interracial heterosexuality produced far more ambivalence: on one hand, it expanded the black man's agency by enlarging his sexual domain; on the other hand, it betrayed a weakness for the forbidden fruit and the potential dilution of strong black bloodlines. Interracial heterosexuality for black women, then as now, was often the object of severe disapproval. $)^{44}$ It is through his break with Village bohemia that Baraka refigures it as a white bohemia, the site of sexually deviant transgressions of weak, effeminate white men. In this way, the discursive poles of a strong black male heterosexuality and a soft, white, male homosexuality fall quickly into place, animating Baraka's writing in this period. His famous 1965 essay, "American Sexual Reference: Black Male," begins with the bracing, but representative, declaration: "Most American white men are trained to be fags." 45

A few years later, Baraka published the short play Rockgroup, which featured " 4 boys in whiteface" wearing "Beetle suits" in a band called the "Crackers." 46 The action of the play is relatively straightforward: the band is introduced, takes the stage, sets up, and performs a song ("White shit white shit white shit 
/ hocus-pocus in the clouds all right"). After their brief concert, the Crackers bow to the effusive applause of the crowd, "dainty and faggish and removed from reality swaggering like toygirls." ${ }^{77}$ As dollars rain down from above, the band collects the money and packs up their instruments; it is revealed that their "geetahs" were plugged into the rear end of a black man who had been slumped underneath a black cloth at the back of the stage during the performance. The man wears tawdry remnants of a showbiz career: "falling down konk and raggidy sequined stage evening clothes." The Crackers place this secret source of their power into a traveling case, placating him with a little money, some "white powder," and "then one of the white boys put on a lady outfit, and kiss him on lips, then nigger, he swoon dead away in box, and white boys carry him off with them."

With this final flourish, Baraka not only criticizes his own past interracialism by lumping it in with economic exploitation and drug abuse, but he also casts white men as the "dainty toygirls" who seduce and deceive black men. As Robyn Wiegman argues, "inverting the representational economy that depicts that black man as either literally or metaphorically less than a man, Baraka aligns feminization with whiteness, defining white men as 'effeminate and perverted." 48 It is worth pointing out that many, if not most, of the downtown bohemian "whites" rejected by Baraka were in fact Jewish. Jeffrey Melnick has recently advanced a persuasive hidden history of black-Jewish male homoeroticism that is clearly pertinent here, yet Baraka continually elided the difference between Jewishness and whiteness, indicating that his move uptown effected a certain simplification of racial difference. ${ }^{49}$ Given the traditional feminization of the male Jewish body, Baraka's rhetorical strategy effectively minimized the difference between "whiteness" and "effeminacy" by lumping Jewishness and whiteness together. ${ }^{50}$ At any rate, the collapsing distinction between interracial romance and male homoerotic seduction in Rockgroup suggests that by 1969, at the height of his cultural nationalist years, Baraka viewed his earlier bohemian period as a blur of cross-racial hetero- and homoerotic sexual energy that required a forceful rejection in the reorientation toward black nationalism.

According to Moten, Cecil Taylor is one of the specters that haunt Baraka's break with downtown, for Taylor avoided a clear presentation of straight, queer, gay, or bisexual identity. This ambivalent sexual presentation, queering him in the eyes of others, was problematic in the context of what Hill Collins describes as "a hegemonic discourse of Black sexuality that has at its core ideas about an assumed promiscuity among heterosexual African American men and women and the impossibility of homosexuality among Black gays and 
lesbians. ${ }^{" 11}$ Nonetheless, Taylor had earned unassailable credentials as a leader of the black avant-garde by the mid-1960s, even as his problematic sexual ambivalence seemed to cut across and destabilize the moral fundamentalism of Black Arts heterosexuality.

This figuration of Taylor as ambivalence shows up in Baraka's 1965 review of a performance by Pharoah Sanders, Marion Brown, and former Guild member Burton Greene: "Greene's 'style' is pointed, I would presume, in the direction of Cecil Taylor and, I would also suppose, with Taylor, the Euro-American, Tudor-Cage, Stockhausen-Wolf [sic]-Cowell-Feldman interpretations." 52 Within that "certain moral fundamentalism" that grounds Baraka's analysis in this passage, two liminal figures emerge to mediate musical difference along parallel axes of race and sexuality. Greene's Jewish identity mediates the racial binarism of strong black jazz and weak white avant-gardism (though Baraka clearly places him closer to the latter), while Taylor's elusive sexuality floats between heteronormative blackness and male homosexual Jewish/whiteness (as hip to the "Euro-American" scene as anyone, Baraka was undoubtedly aware of the non-normative sexualities of Cage, Tudor, and Cowell). Through the doubled inscription of Greene's style "toward the direction of Cecil Taylor," Baraka dismisses both whiteness and homosexuality under the cover of musical style.

In one of his more deliriously analytical passages, Moten asks, "Is jazz a kind of closet, a withdrawal of (homo)sexuality negatively echoed in real and mythical carnal origins in explicit and illicit (hetero)sexuality?" He continues,

But what of the inevitable... (primarily male homo)erotics of ensemble or of the feminized romanticism of a pianism of the body that is never not racialized, never not coded as the non-European, as the non-European within the European, even as it is coded as effeminate, overemotional, lustful, uncontrolled, animalistic or, at least, infused with too much anima, possessed, transportive, out, ecstatic, gay? ${ }^{53}$

Moten means to show that the heteronormativity of black nationalism is conditioned by —and thus threatened and haunted by—an erotics of emotional, rapturous male bodies in concert, coded by another dominant racial discourse as non-European, uncontrolled, and animalistic.

If jazz was "a kind of closet," then the responses to a 1966 Sounds \& Fury column on jazz homosexuality would seem to offer evidence. Contributing editor Jean French asked ten professional jazz musicians, "It is claimed that homosexuality is almost non-existent among jazz musicians as compared to other limbs in the tree of show business-your opinion?" 54 While two musicians replied with predictable denial—Attila Zoller, for example, answered, 
"I agree with that! Jazz musicians are too busy blowing their horns"-six others acknowledged a measure of male homosexuality, but stressed that it was a private matter. "Some of my best friends are homosexuals. My father once told me, 'one man's pleasure is another man's poison,"” said Lee Morgan, while Curtis Fuller replied, "Wherever it does exist, I believe it to be a personal subject and as far as I'm concerned, up to the individual." Herbie Hancock offered a helpful correction: "I think you'll find its existence more bi-sexual than homosexual." The responses of Sonny Rollins ("There's something very masculine in playing jazz but there are homosexuals too") and Bobby Hutcherson ("That's very true! Jazz musicians are all men. Jazz is a masculine emotion. It portrays more masculine emotion than feminine. It can be a masculine sweet and beautiful. Female jazz musicians tend to be more masculine than feminine") portrayed jazz as a masculine art, implying that (black) masculinity is outside of or incompatible with homosexuality. 55

As we have seen, this mutual exclusion also underlay Baraka's understanding of black masculinity as necessarily heterosexual, and also necessarily opposed to a white homosexuality. In a context of material deprivation, marked by nonexistent or limited employment opportunities and unequal wage structures, the discourse of "fundamentalist" black heterosexual masculinity provided a discursive realignment of power toward those to whom it had historically been denied. (Indeed, the status of women as significant wage earners in the African American community surely contributed to this articulation of black male power.) Furthermore, jazz was one arena wherein labor itself could be reframed as a (black) male activity. ${ }^{56}$ Although Dixon was suspicious of the linkages between black nationalism and avant-garde jazz, he shared Spellman's view of the music as men's work. Dixon explains, "If you saw, at any of the sessions, two or three women, that's because they were hip and wanted to know. The rest of the women were not remotely interested in this music. There was no 'sexism' [laughs].... There were a whole lot of women singers, cocktail pianists, I mean, there were very few people who were like Mary Lou Williams and those people, because first of all, the life was so rough, and the men-if you want to look at it, here's a guy works in the garment center all day, taking all that crap, going through that stuff, but he's got his horn, comes home, and goes out and plays - it was the only thing these guys had!" Later in the interview, Dixon clarified, "I can tell you this: it was a male-dominated music, because that's what the men wanted to do. They wanted to play, and they had no problems playing for hours, rehearsing for hours, doing all this kind of stuff." 57 
This was the aggressively masculine social environment of jazz in general and the Guild in particular, a context in which Roswell Rudd's positive memory of a "certain amount of good competitiveness" at the October Revolution in Jazz takes on a different meaning when considered from the perspective of a female instrumentalist or composer who might feel less willing to participate in a such a contest. In fact, Carla Bley's invitation to join the Guild was extended only after some debate among the other members. Dixon recalls, "I had to really be very, very severe with the Guild. They didn't want Carla in the group, because of Sun Ra. Sun Ra was against it. My feeling was, first of all, Carla at the time wrote all of the music for Paul Bley, so she was one half of Paul, so she deserved it." 58 Bley's presence apparently did little to alter the belligerent and famously antagonistic mood of Guild meetings, which in her memory were full of shouting and challenges to "put it on the table!"59 She had a direct run-in of her own with Sun Ra. Well known as a misogynist who discouraged women from entering the Arkestra's communal living and rehearsal spaces, Ra did eventually invite the vocalist and dancer June Tyson into the band, though he still banished her from the recording studio if a session wasn't going well. ${ }^{60}$ When things began turning sour in the Guild, he recounted the old seamen's legend that says that taking a woman on a voyage will sink the ship. ${ }^{61}$ Though painfully shy, Bley did not take this abuse quietly, and remembers the shouting match that ensued and her angry departure from the meeting. As Bernard Stollman, who sat in on an early meeting of the Guild, told me in 2006, "she was an iron lady then, as she is now." 62

Though Bley could apparently go toe-to-toe with other Guild members when pressed, other anecdotal evidence suggests the ways that she was viewed differently from her male colleagues. One musician who was not a member of the collective, but who played in a group with Guild musicians, recalled that he enjoyed frequenting Guild events because he thought Bley was attractive. Another exceedingly polite and helpful (male) member was discussing all the sidetracks the group pursued during the course of an ordinary meeting. When asked about the subject of these digressions, he replied, "Oh, anything! It could have been about ... pussy! Well, if Carla wasn't there." This flippant but revealing comment indicates that Bley's gender was present at meetings even in her absence, and that there was certain "business" that could be conducted only among male members of the Guild. Moreover, it shows how the exclusion of women in these jazz spaces performed a consolidation of male homosociality as much as it did misogyny.

Though Carla Bley's presence at Guild events clearly changed the social dynamic in certain ways, her acceptance into the new thing community was 
largely based on the gender-evasive ideology of the "exceptional woman." In using the term "gender-evasive" here, I am borrowing Frankenberg's concepts of color-evasiveness and power-evasiveness. Like these two descriptions of racial ideology, gender-evasion implies a turn away from the analysis of gender as a modality of power, a component in a larger social formation structured in dominance. Without this broader view, gender oppression registers only as the result of individual malice or unreconstructed chauvinism. If these negative motivations are absent, gender is thought to have exited the equation. As Mantler remembered it, "I don't think there was anything special about there being a woman in the group.... Carla was accepted like anyone else." ${ }^{63}$ Because there were so few women in the black experimental scene, Bley's membership in the Guild was thought to have proven that gender was not a constitutive force in the community, and that anyone-man or woman — with enough skills and talent would succeed. By means of this merit-based and gender-blind ideology, an "exceptional" woman like Carla Bley was permitted to enter the discourse without significantly changing it. ${ }^{64}$

The prominent female musicians of this period-Patty Waters, Abbey Lincoln, Jay Clayton, Jeanne Lee-were all singers, a devalued category of creative artist that suffered from its associations with mere "entertainment" or pop singing, and also due to the emphasis placed on instrumental skill. Eric Porter has demonstrated how the masculinist values of Baraka and Shepp led them to dismiss such "crossover" stars as Dionne Warwick for being too "white," too commercial, or simply incapable of articulating an intellectual position on black cultural politics. ${ }^{65}$ For the generation of vocalists coming of age in the 1950s, the case of Lincoln is representative. According to Porter, her performance in Max Roach's We Insist! The Freedom Now Suite showcased a nuanced sense of rhythm, phrasing, and timbre that effected an "instrumentalized" approach to the voice, and created a place for her alongside the men in Roach's band. In this case, Lincoln became a "musician" to the extent that she was able to transform her voice into another front-line instrument.

Whereas Lincoln's marriage to Roach helped her to move out of the role of entertainer, it is commonly understood that Albert Ayler's relationship with Mary Parks (who performed under the name "Mary Maria") pulled him in the opposite direction, a narrative that would seem to support the equation of womanhood with commerce and "selling out." Valerie Wilmer, for example, writes that "from a critical point of view their relationship led to some of his least stimulating music," including Ayler's 1968 attempt at crossover success, New Grass, which Wilmer described as "an unconvincing excursion into rhythm-and-blues territory." ${ }^{\prime 66}$ Yet Wilmer acknowledges elsewhere in her 
valuable appraisal of Ayler's life and work that the saxophonist himself credited Impulse! producer Bob Thiele—and not Parks—with pressuring Ayler into experimenting with more popular styles. Nonetheless, the trope of a successminded girlfriend leading our star astray has proven durable; in his excellent online bio-discography of Ayler, Jeff Schwartz writes, "It is likely, however, that the dominant influence on [New Grass], and Albert's following recordings, rather than the record company, was, as [collaborator] Call Cobbs said, Mary Parks. ${ }^{" 67}$ Kasper Collin's recent documentary film My Name Is Albert Ayleralso contends that Parks pushed him to record in a more accessible style. ${ }^{68}$

In a recently published interview with Kiyoshi Koyama from July 1970, Ayler unequivocally names Thiele as the impetus behind New Grass—according to Ayler, Thiele told him, "Look, Albert, you've got to get with the younger generation." ${ }^{\prime 9}$ Moreover, Ayler clearly liked his new sound: "But when I made it [New Grass], I made it as good, or better, than they ever heard before!” Ayler's enthusiasm for the rock-influenced sound he explored at the end of the 1960s certainly complicated the common repudiation of Parks as a corrupting force in his professional life. In this regard, Wilmer equivocates somewhat in her reportage: "Many musicians have suggested that she exercised an undue hold over him, yet their relationship seems to have been a mutually satisfying one. ${ }^{70}$ In My Name Is Albert Ayler, Collin includes a fascinating snippet of audio from a telephone conversation with Parks in which the latter explains that she would prefer not to be interviewed for the film, and that she could "enhance the sense of mystery" by remaining off camera. Parks's reluctance to be pictured, her withdrawal into mystery, can be understood as a certain desire for nondefinition and a preemptive rejection of the terms through which her subjectivity would be formed in a masculinist jazz discourse.

In her dissertation on the life and music of Alice Coltrane, Franya Berkman writes of the same conundrum-if scholarship on 1960s jazz has either retreated from social concerns to concentrate on formal musical properties or interpellated musicians into a rigid model of radical black subjectivity, she observes, then Alice Coltrane's deeply religious practice of music making and her commitment to a universalist spiritual politics seems to overflow the available terms of the conversation. ${ }^{71}$ Moreover, as Berkman tells it, Alice Coltrane was a bad fit in the prevailing (white) feminist narrative of achieving equality with men, as autonomous, self-sustaining subjects, because she achieved selfrealization through her family, not in spite of it: "What we see in her playing with John Coltrane's late quintet is the 'manifestation' of her unfettered creative self made strong by the depth of her commitment to her family, her husband's musical vision, and to a spiritual path of self-realization." 72 
Like Alice Coltrane (and, indeed, preceding her in this milieu), Carla Bley's identity as a composer (and occasional pianist) was at odds with a musical world that admitted so few women into its ranks, and also suggests the ways in which she performed partial identities in different contexts to either challenge or survive dominant notions of "women-in-jazz." 73 Among the obstacles she faced was the specific manner in which command and authority were linked to masculinity in a jazz setting. In European musical discourse the mastery of masculinity is enacted through an escape from the body into the immaterial realm of abstract form, computational logics, and creative production, an escape that depends on the concomitant linkage of embodiment with femininity, obedience, and reproduction. ${ }^{74}$ But, as Monique Guillory observes, "the black, male body that symbolizes an exceptional standard of performance in jazz, hip hop, and basketball rests largely on a particular construct of black masculinity that inscribes the performative nature of each activity." 75 Indeed, mastery in the discourse of 1960s jazz seems to have been based more on physical prowess and embodied domination on the bandstand than on disembodied abstraction - it is there, in the sweaty brow of the laboring soloist, in the "big massive sound and wail" of Ayler. "Shepp dominates this group. His style is hard and overpowering." This channeling of the language of control into African American bodily practices is not particularly surprising, given the ingrained racial patterning that assigns powers of the mind and culture to European agents while the dancing body animated by black music becomes, in the words of Susan McClary and Rob Walser, "romanticized as what is left over when the burdens of reason and civilization have been flung away." 76 What's interesting is the mutability of the masculine across these two interdependent cultural formations - in one retreating to the mind as if the body didn't exist, and in the other, manifesting in physical dominance as if thought played no role at all.

If credibility, virtuosity, and perhaps even artistry itself was attached in 1960s jazz discourse to the performing labors of the black male body, then Carla Bley's white womanhood and merely passable skills at the piano meant that her creative leadership would have to take a different form. Her comments in later interviews indicate that she viewed her own development at this time in terms of a growing race consciousness that arose in response to her African American colleagues in the avant-garde jazz world of New York City. As she explained to Times critic John Wilson after returning from Europe in 1967, the black nationalism of 1964-65 felt to her like a rejection. "I began to get an overview of myself as a white woman," she commented. "I realized I had European roots, so why was I trying to find African roots? I'd 
been like a bastard - if you're a bastard, you don't inherit. I decided if they don't want me, I don't want them." ${ }^{.77}$ Bley's remarks in a 1987 interview suggest an indexing of these "roots" to modalities of musical creativity. Recalling her time in the Guild, she observed, "It was a revolution, in a sort, that we had! And they called themselves composers because they thought improvisation was spontaneous composition. But . . . I was a real composer; I couldn't improvise at all." ${ }^{\prime 7}$

In contrast to African American women such as Lincoln, who developed new uses of the voice to claim a place on the bandstand, Carla Bley created her space as an author of music, rather than a performer. While this clearly marked her as not being "one of the guys," it also elevated her into the realm of abstract compositional process long thought to be the domain of white men only. Not only did she write music for several male performers, but she was also the eventual co-leader of the Jazz Composer's Guild Orchestra, which began as an ensemble of several of the leading members of the organization (Shepp, Mantler, Rudd, Tchicai, and Paul Bley) and added in the years to come such other prominent male players as Steve Lacy, Jimmy Lyons, Eddie Gomez, Milford Graves, Sam Rivers, Lee Konitz, Marion Brown, and Paul Motian.

Carla Bley's position as creator and as leader of men coexisted with her other more marginalized roles as a shy white woman and wife. ${ }^{79}$ Indeed, biographical accounts rarely fail to mention the importance of more established male musicians in starting her career. The entry for Bley in The New Grove Dictionary of Jazz is representative: "At the age of 17 she moved to New York, where she worked intermittently as a pianist and cigarette girl. In the latter capacity she met Paul Bley, whom she married in 1957 and who persuaded her to write miniature jazz themes for his albums. Some of these compositions were also taken up by George Russell and Jimmy Giuffre." ${ }^{\prime 0}$ In writing these "miniature themes," Carla Bley was able to participate musically in this jazz world without participating bodily - that is, as a performer, where she would have more directly confronted the overwhelmingly male homosocial realm of the new thing. Her entrance to this community was smoothed by having her husband play her compositions. During the Guild months, Carla Bley separated from Paul and began a new and productive romantic relationship with Michael Mantler, with whom she co-led the orchestra and other smaller ensembles. Again, her husband was the public, organizing force of the collaboration-Mantler recounts that "all administration, fund-raising, organizing, etc., had been my work from the very beginning to the end (of course with Carla's 'public relations' input, etc.)." ${ }^{81}$ 
I am most certainly not implying that Carla Bley relied upon her male partners to advance an otherwise undeserving career. On the contrary, I am suggesting that this performance of white womanhood was required to achieve success in a context where women's roles were so severely limited, and where her voice would otherwise simply not register. Her marriage first to Paul Bley and then to Mantler removed her somewhat from the sexual economy of jazz bohemia, and thus she gained not only the "respect" that comes with being a serious composer, but also the "respectability" of a married white woman. ${ }^{82}$ Through this process, she was enlisted into what Frankenberg calls the "tropeical family," a dominant set of images that construct gender along racial lines. ${ }^{83}$ The repertoire of stereotypes is small, a quartet consisting of White Woman, White Man, Man of Color, and Woman of Color. White Woman is vulnerable and delicate, while White Man is her strong, self-designated protector. Man of Color is the sexually rapacious predator, and Woman of Color is also sexually eager, but balanced on the line between seductive and repulsive. These tropes are co-constructed in and through relation with one another, and always hierarchically. ${ }^{84}$ Thus, "White Man as protector" means nothing without notions of White Woman's frailty, and also depends on Man of Color's supposed sexual aggression. ${ }^{85}$

Recent scholarship in Jewish cultural studies has enriched and complicated Frankenberg's schematic of race relations, detailing the ways in which blackJewish relations in the United States are specific and complex, and suggesting that Jewish masculinity was defined less by the trope of protection than by an occlusion of femininity and identification with black hypermasculinity. ${ }^{86}$ Such a difference takes shape in light of long-standing representations of the Jewish male body as weak, feminized, defective, or diseased, especially in a postwar environment still coming to terms with photographic evidence of the Nazi Holocaust. As Andrea Levine makes clear in her analysis of Norman Mailer's "The White Negro," these engagements "between men" almost always enroll the feminine, albeit toward varying ends. For the more aggressive strains of black nationalism, masculine heteronormativity was a means of asserting power over all women and nonblack men, while Mailer's feminization and occlusion of Jewishness facilitated a rearticulation of racial identity, and thus "functioned successfully to re-write white Negroism as exactly that-white Negroism." ${ }^{77}$ Melnick further notes that the masculinist slant of black-Jewish relations has drawn attention away from a potentially troublesome issue such as miscegenation, a topic broached by Malcolm X in his debates with Baraka (whose "white" wife was in fact Jewish, born Hettie Cohen). Jewishness may have related closely to whiteness, but, as Josh Kun states, "for Jews, whiteness 
was (and I would argue, still is) never a given; it is always a status to be granted or denied, but never a status that could be inherently, rightfully, owned." 88

Once again, we are reminded of the ways in which gender and race are coconstituted, and the particular discourse of masculinity being deployed at this time. Carla Bley's performance of the white wife simultaneously projected the threat of the black sexual predator, an image that Baraka was all too willing to provide in 1965, when he described black men as "basic and elemental . . . , therefore 'wilder,' harder, and almost insatiable in his lovemaking." ${ }^{89}$ The essentialism here must be understood as emerging from a subaltern position in the social field, distinguishing Baraka's rhetoric from similar figurations of black masculinity by white or Jewish writers such as Mailer. ${ }^{90}$ Nonetheless, it is perhaps only one link further along the discursive chain of virility that was cultivated by the Black Arts writers and that manifested in their jazz criticism of the time. Tracing these many links reveals that gender functioned as a system that related all of these individual subjects to each other, and to other discourses such as race and aesthetics in the New York jazz underground.

Although scholarly treatments of the Jazz Composers Guild are limited in number and scope, they are all directed toward the competing racial discourses surrounding the group, and this focus reflects that of other important studies concerned above all with explaining the racial politics of black music in the 1960s. ${ }^{11}$ According to this account, the conflicts surrounding the Guild can be sorted into the general opposition of class-based politics versus race-based nationalism, a tension that was, by the 1960 s, several decades old. ${ }^{92}$ While Dixon's position sounded the tonalities of left labor politics, Baraka and his cohort were more insistent on the specificities of racial oppression and the failure of historical materialism to address these concerns. Meanwhile, some musicians, such as Shepp and Taylor, seemed to float between these poles. Although these positions on race and class clearly structured interactions among members of the jazz underground during this period, I hope to have shown that there is a parallel history of gender and sexuality woven into this story, one that has been obscured by the greater emphasis placed on race and resistance. This tendency to bypass analyses of the gender dynamics of avant-garde jazz and black nationalism was exacerbated by a white women's movement that was tone deaf to matters of race, despite an emerging black feminism that refused to separate matters of racial inequality and gender inequality. ${ }^{93}$

I've focused this essay on a single musicians' collective because I believe that discourses of gender and sexuality require careful attention to specifics in historical studies such as this one. Though comparable detailed analyses of these discourses in other alternative African American cultural institutions of 
the period are still needed, one can reasonably speculate that a similar hidden history lies beneath the standard story in each of these institutional contexts. ${ }^{94}$ The case of the Jazz Composers Guild demonstrates that patterns of gender and sexuality not only constituted a discursive web through which racial politics were expressed and enacted, but also sounded their own particular dissonances and silences in the historical record.

\section{Notes}

I thank Sherrie Tucker, Ellie Hisama, Monica Hairston, and the editors of American Quarterly for reading drafts of this article. All remaining faults are my own.

1. See Martin Williams and Dan Morgenstern, "The October Revolution: Two Views of the Avant Garde in Action," Down Beat, November 19, 1964, 15-16; and Dan Carlinsky, "Jazz in a Cellar," Columbia Daily Spectator, October 7, 1964, 2.

2. For more on the avant-garde jazz scene in New York from the late 1950s, see LeRoi Jones [Amiri Baraka], "New York Loft and Coffee Shop Jazz," in Black Music (1963; New York: William Morrow, 1967), 92-98; and Ben Young, Dixonia: A Bio-Discography of Bill Dixon(Westport, Conn.: Greenwood Press, 1998).

3. For a history of the Guild, see Benjamin Piekut, "Race, Community, and Conflict in the Jazz Composers Guild," Jazz Perspectives 3.3 (December 2009): 191-231; see also Valerie Wilmer, As Serious as Your Life: John Coltrane and Beyond (1977; London: Serpent's Tail, 1992), 213-15; Philippe Carles and Jean-Louis Comolli, Free Jazz/Black Power (Paris: Éditions Champ Libre, 1971), 50-51; Ekkehard Jost, Sozialgeschichte des Jazz in den USA (Frankfurt: Fischer Taschenbuch Verlag, 1982), 212-14; Iain Anderson, This Is Our Music: Free Jazz, the Sixties, and American Culture (Philadelphia: University of Pennsylvania Press, 2006), 138-41; Narada Burton Greene, Memoirs of a Musical "Pesty Mystic," or, From the Ashcan to the Ashram and Back Again (Redwood, NY: Cadence Jazz Books, 2001), 36-40; Paul Bley and David Lee, Stopping Time: Paul Bley and the Transformation of Jazz (Montreal: Véhicule Press, 1999), 91-97; Robert Levin, “The Jazz Composers Guild: An Assertion of Dignity,” Down Beat, May 6, 1965, 17-18; and "Quelques Hommes En Colere," Jazz Magazine 120 (July 1965): 16. The most complete and useful source on Dixon and his role as an organizer in the New York underground remains Young's Dixonia.

4. "Avant Garde Organizes, to Present Concert Series," Down Beat, December 31, 1964, 10; John S. Wilson, "Avant-Garde Jazz Series Offers Cecil Taylor and Dixon Quintet," New York Times, December 29, 1964; Don Heckman, "Caught in the Act: The Jazz Composers Guild,” Down Beat, February 11, 1965, 37-38; Wilson, “Dig That Free-Form Jazz,” New York Times, January 24, 1965; A. B. Spellman, "Jazz at the Judson," The Nation, February 8, 1965, 149-51; and Whitney Balliett, "Comes the Revolution," New Yorker, February 27, 1965, 121-24.

5. Jacques Attali, Noise: The Political Economy of Music (Minneapolis: University of Minnesota Press, 1985), 138.

6. Clifford Allen, "Bernard Stollman: The ESP-Disk Story," All About Jazz, November 21, 2005, http://www.allaboutjazz.com/php/article.php?id=19661 (accessed October 17, 2006); Ralph Berton, "Conversations with Bernard Stollman," Sounds \& Fury, April 1966, 36-38; and Bernard Stollman, interview with the author, New York City, December 5, 2006.

7. Dixon's disagreement with Baraka showed up in 1965 during the question and answer period of an important panel discussion on "Jazz and Revolutionary Black Nationalism" in December 1965 (transcribed and printed serially in Jazz in 1966 and 1967).

8. See LeRoi Jones [Amiri Baraka], "Apple Cores," Down Beat, December 17, 1964, 40. A. B. Spellman was another member of the Baraka circle who had little respect for Dixon's work. In his review of the "Four Days in December," Spellman wrote, "Dixon is a far better organizer than musician." See Spellman, "Jazz at the Judson," 150. 
9. See "Dixon Digs at Jones," Down Beat, January 2, 1964, 8-9.

10. LeRoi Jones [Amiri Baraka], "Strong Voices in Today's Black Music," Down Beat, February 10, 1966, 15; and Robert Levin, "Some Observations on the State of the Scene," Sounds \& Fury, July-August 1965,5 .

11. For an examination of gossip in the art world of postwar New York, see Gavin Butt, Between You and Me: Queer Disclosures in the New York Art World, 1948-1963 (Durham, NC: Duke University Press, 2005).

12. Sherrie Tucker, "Big Ears: Listening for Gender in Jazz Studies," Current Musicology 71-73 (Spring 2001-Spring 2002): 377.

13. George E. Lewis, A Power Stronger Than Itself: The AACM and American Experimental Music (Chicago: University of Chicago Press, 2008), 113-14.

14. Roswell Rudd, interview with the author, New York City, October 5, 2006; on the Collective Black Artists, see Eric Porter, What Is This Thing Called Jazz? African American Musicians as Artists, Critics, and Activists (Berkeley: University of California Press, 2002), 215-39.

15. Eric Drott, "Free Jazz and the French Critic," Journal of the American Musicological Society 61.3 (Fall 2008): 541-81.

16. Ingrid Monson, Freedom Sounds: Civil Rights Call Out to Jazz and Africa (New York: Oxford University Press, 2007), 170.

17. Tammy Kernodle, “I Wish I Knew How It Would Feel to Be Free’: Nina Simone and the Redefining of the Freedom Song of the 1960s," Journal of the Society for American Music 2.3 (August 2008): 295-317; Brian Ward, Just My Soul Responding: Rhythm and Blues, Black Consciousness, and Race Relations (Berkeley: University of California Press, 1998).

18. Michael Mantler, telephone interview with the author, October 29, 2006.

19. Milford Graves, interview with the author, Jamaica, NY, January 23, 2007.

20. Bill Dixon, in "Bill Dixon," Sounds \& Fury, July-August 1965, 39.

21. See Tucker, "Big Ears"; David Ake, "Regendering Jazz: Ornette Coleman and the New York Scene in the Late 1950s," in Jazz Cultures (Berkeley: University of California Press, 2002), 62-82; Ingrid Monson, "The Problem with White Hipness: Race, Gender, and Cultural Conceptions in Jazz Historical Discourse," Journal of the American Musicological Society 48 (1995): 396-422; Nichole T. Rustin, "Mingus Fingers: Charles Mingus, Black Masculinity, and Postwar Jazz Culture" (PhD diss., New York University, 1999); Porter, What Is This Thing Called Jazz?); Monique Guillory, "'Black Bodies Swingin': Race, Gender, and Jazz," in Soul: Black Power, Politics, and Pleasure, ed. Monique Guillory and Richard C. Green, 191-215 (New York: New York University Press, 1998); and Krin Gabbard, "Signifyin(g) the Phallus: Mo' Better Blues and Representations of the Jazz Trumpet," in Representing Jazz, ed. Krin Gabbard, 104-30 (Durham, NC: Duke University Press, 1995).

22. Imamu Amiri Baraka, The Autobiography of LeRoi Jones (Chicago: Lawrence Hill Books, 1984), 286.

23. Ekkehard Jost, Free Jazz (1975; New York: Da Capo Press, 1994), 106.

24. Cecil Taylor, ;Conquistador! Blue Note 90840 (1966), 2004.

25. Spellman, "Jazz at the Judson," 150.

26. Ibid., 151.

27. Harold Cruse, The Crisis of the Negro Intellectual: A Historical Analysis of the Failure of Black Leadership (1967; New York: New York Review Books, 2005), 363-65.

28. Monson, "The Problem with White Hipness," 417-18.

29. Bill Dixon, interview with the author, Bennington, VT, August 15, 2006.

30. Baraka, Autobiography of LeRoi Jones, 286. See also Jerry Gafio Watts, Amiri Baraka: The Politics and Art of a Black Intellectual (New York: New York University Press, 2001), 135-40; and Cruse, Crisis of the Negro Intellectual, 364-65, 486-87.

31. As Jason Robinson and Eric Porter point out, Shepp's position on black nationalism and revolutionary politics differed from Baraka's, despite the similarity of their rhetoric. In Jazz's panel discussion of December 1965, Shepp articulates a more traditional class-based analysis of racial oppression and resists the radical polarization of black and white that was central to the Black Arts writers and thinkers. See Robinson, "The Challenge of the Changing Same: The Jazz Avant-garde of the 1960s, the Black Aesthetic, and the Black Arts Movement," Critical Studies in Improvisation 1.2 (2005): 27; and Porter, What Is This Thing Called Jazz? 200-207. 
32. I haven't yet identified this publication; photocopy in Archie Shepp clipping file, Institute of Jazz Studies, Rutgers University. The photocopy is marked "Nov. 1967."

33. Patricia Hill Collins, Fighting Words: Black Women and the Search for Justice (Minneapolis: University of Minnesota Press, 1998), 168.

34. Ibid., 171. For Hettie Jones's account of her marriage to Baraka, see Hettie Jones, How I Became Hettie Jones (New York: E. P. Dutton, 1990).

35. Larry Nai, "Marzette Watts Interview," Cadence 24.8 (1998): 13-14.

36. Jones, How I Became Hettie Jones, 218. For another discussion of the sexual politics of black nationalism, see Lewis, Power Stronger Than Itself, 200-204.

37. Abbey Lincoln, "Who Will Revere the Black Woman?" in The Black Woman, ed. Toni Cade (1966; New York: New American Library, 1970), 83, quoted in Farah Jasmine Griffin, If You Can't Be Free, Be a Mystery: In Search of Billie Holiday (New York: Free Press, 2001), 179.

38. Griffin, If You Can't Be Free, Be a Mystery, 181.

39. Winifred Breines, The Trouble Between Us: An Uneasy History of White and Black Women in the Feminist Movement (New York: Oxford University Press, 2006), 55-56; see also Robyn Wiegman, American Anatomies: Theorizing Race and Gender (Durham, NC: Duke University Press, 1995).

40. Fred Moten, In the Break: The Aesthetics of the Black Radical Tradition (Minneapolis: University of Minnesota Press, 2003).

41. Monson, "The Problem with White Hipness," 397.

42. Moten, In the Break, 281n102.

43. Which is not to say that the Village was a haven for interracial couples or open homosexuality. Cecil Taylor was attacked late one spring night on the lower east side in 1964, and his left wrist was broken in the scuffle. The short description of the incident in Down Beat notes that the assailants were never caught by the police. Whether this was a hate crime-and, if so, whether it concerned race or sexuality—is unknown; see "Cecil Taylor Attacked on Street; Wrist Broken," Down Beat, August 27, 1964. For more on the dangers of Greenwich Village for African American bohemians, see Jon Panish, The Color of Jazz: Race and Representation in Postwar American Culture (Jackson: University Press of Mississippi, 1997), 23-41.

44. See Patricia Hill Collins, Black Sexual Politics: African Americans, Gender, and the New Racism (New York: Routledge, 2004).

45. LeRoi Jones [Amiri Baraka], "American Sexual Reference: Black Male," in Home: Social Essays (1965; New York: William Morrow, 1966), 216. For an extended theoretical analysis of this dynamic, see Hill Collins, Black Sexual Politics, 87-116.

46. Amiri Baraka, "Rockgroup," The Cricket 4 (1969): 41-43.

47. Ibid., 42.

48. Wiegman, American Anatomies, 107.

49. Jeffrey Melnick, "Some Notes on the Erotics of 'Black-Jewish Relations," Shofar: An Interdisciplinary Journal of Jewish Studies 23.4 (2005): 9-25. Baraka's Autobiography provides innumerable examples on this point: Hettie Cohen was his "white wife," while murdered civil rights workers Andrew Goodman and Michael Schwerner were "white boys... seeking to assuage their own leaking consciences" (285).

50. Several authors discuss the gendering of Jewishness as a racial category; see, for example, Sander Gilman, Freud, Race, and Gender (New York: Routledge, 1993), and Ann Pellegrini, "Whiteface Performances: 'Race,' Gender, and Jewish Bodies," in Jews and Other Differences: The New Jewish Cultural Studies, ed. Jonathan Boyarin and Daniel Boyarin, 108-49 (Minneapolis: University of Minnesota Press, 1997). The emerging antagonism between black nationalism and Jewish leftism during the 1960s is discussed in Melnick, "Some Notes," 23; and Andrea Levine, "The (Jewish) White Negro: Norman Mailer's Racial Bodies," MELUS 28.2 (2003): 76.

51. Hill Collins, Black Sexual Politics, 97-98.

52. Baraka, "The Burton Greene Affair," Down Beat, August 25, 1965, 13.

53. Moten, In the Break, 161.

54. Jean French, "It's Like This," Sounds \& Fury, September-October 1965, 52-53.

55. Hutcherson's remark that "female jazz musicians tend to be more masculine than feminine" points to the double meaning of jazz as "a kind of closet," for lesbian musicians may have found jazz to be a less policed environment for non-normative presentations of gender and sexuality. Although lesbianism 
in 1960s jazz remains an underinvestigated topic, two essays by Sherrie Tucker are required reading: "When Subjects Don't Come Out," in Queer Episodes in Music and Modern Identity, ed. Sophie Fuller and Lloyd Whitesell, 293-310 (Urbana: University of Chicago Press, 2002); and "When Did Jazz Go Straight? A Queer Question for Jazz Studies," Critical Studies in Improvisation 4.2 (2008), http:// www.criticalimprov.com (accessed September 14, 2009).

56. Gendered labor emerges as a key theme in other periods of jazz history; see Patrick Burke, "Oasis of Swing: The Onyx Club, Jazz, and White Masculinity in the Early 1930s," American Music 24.3 (Fall 2006): 320-46; and Porter, What Is This Thing Called Jazz?26-32.

57. Dixon, interview with the author.

58. Ibid.

59. Carla Bley, telephone interview with the author, September 29, 2006.

60. John F. Szwed, Space Is the Place: The Lives and Times of Sun Ra (New York: Da Capo, 1998), 250.

61. Wilmer, As Serious as Your Life, 215.

62. Stollman, interview with the author.

63. Mantler, telephone interview with the author, October 29, 2006.

64. Tucker, "Big Ears," 384.

65. Porter, What Is This Thing Called Jazz? 194 and 204.

66. Wilmer, As Serious as Your Life, 108.

67. Jeff Schwartz, Albert Ayler: His Life and Music, 1992, http://www.geocities.com/jeff_1_schwartz/ayler. html (accessed June 21, 2008).

68. Kasper Collin, director, My Name Is Albert Ayler, 2007.

69. Albert Ayler, interview with Kiyoshi Koyama, Tokyo, July 25, 1970, in Holy Ghost, Revenent Records RVN 213, 2004.

70. Wilmer, As Serious as Your Life, 108.

71. Franya Berkman, "Divine Songs: The Music of Alice Coltrane" (PhD diss., Wesleyan University, 2004).

72. Ibid., 129.

73. I am referring here to Sherrie Tucker's exhortation "to think of 'woman' as a set of changes that can be improvised upon." See Sherrie Tucker, "Bordering on Community: Improvising Women Improvising Women-in-Jazz," in The Other Side of Nowhere: Jazz, Improvisation, and Communities in Dialogue, ed. Daniel Fischlin and Ajay Heble, 244-68 (Middletown, Conn.: Wesleyan University Press, 2004), 263.

74. See, for example, Marcia Citron, Gender and the Musical Canon (Cambridge: Cambridge University Press, 1993); Suzanne G. Cusick, "Gender, Musicology, and Feminism," in Rethinking Music, ed. Nicholas Cook and Mark Everist, 471-98 (Oxford: Oxford University Press, 1999); and Suzanne G. Cusick, "Gender and the Cultural Work of a Classical Music Performance," Repercussions 3.1 (1994): $77-110$.

75. Guillory, "Black Bodies Swingin'," 197.

76. Susan McClary and Rob Walser, "Theorizing the Body in African-American Music," Black Music Research Journal 14.1 (Spring 1994): 76.

77. John S. Wilson, "Don't Call Carla's Jazz Jazz," New York Times, March 17, 1974, 131.

78. Titus Levi, "Under the Volcano: A Conversation with Carla Bley, Steve Swallow, Mike Mantler, and Jack Cummings," Coda 212 (1987): 4-5.

79. Bley described herself in these terms in our telephone interview.

80. New Grove Dictionary of Jazz, s.v. "Bley, Carla [née Borg, Karen]" (by J. Bradford Robinson and Barry Kernfeld), http://www.grovemusic.com (accessed December 16, 2006).

81. Michael Mantler, e-mail communication with the author, December 18, 2006.

82. For more on the concept of "respectability," see Hilary Harris, "Failing White Woman: Interrogating the Performance of Respectability," Theatre Journal 52.2 (May 2000): 183-209.

83. Ruth Frankenberg, "Introduction: Local Whitenesses, Localizing Whiteness," in Displacing Whiteness: Essays in Social and Cultural Criticism, 11-15 (Durham, NC: Duke University Press, 1997).

84. I am grateful to Nadine Hubbs for reminding me that Frankenberg's quartet of race and gender is also conditioned by class—-working-class white women are rarely figured as vulnerable or delicate, and thus have never warranted "protection," as middle- or upper-class white women have. Nonetheless, in at least one important historical example, it was precisely an encounter with black masculinity that 
enacted racial difference in the name of protection: with her husband, Roy, Carolyn Bryant was the white working-class owner of a small shop in rural Mississippi when fourteen-year-old Emmett Till flirted with her on the way out of the store. This innocent gesture led to the murder of Till at the hands of Roy Bryant and his half-brother, J. W. Milam, in the summer of 1955.

85. See also Farah Jasmine Griffin, "Ironies of the Saint': Malcolm X, Black Women, and the Price of Protection," in Sisters in the Struggle: African-American Women in the Civil Rights and Black Power Movements, ed. Betty Collier-Thomas, 214-29 (New York: New York University Press, 2001).

86. See Levine, "The (Jewish) White Negro"; Josh Kun, "Bagels, Bongos, and Yiddishe Mambos, Or the Other History of Jews in America," in Shofar: An Interdisciplinary Journal of Jewish Studies 23.4 (2005): 50-68; and Melnick, "Some Notes." In the case of the Guild, the roles of Jews as business partners (Stollman), musical collaborators (Greene), or romantic partners (Hettie Jones) call attention to the limits of Frankenberg's system.

87. Levine, "The (Jewish) White Negro," 60. Jewish femininity has received less critical attention, owing perhaps to the emphasis on narratives of male cooperation. See Melnick, "Some Notes," 11.

88. Kun, "Bagels, Bongos, and Yiddishe Mambos," 53.

89. Baraka, "American Sexual Reference," 223.

90. Norman Mailer, "The White Negro (Superficial Reflections on the Hipster)," Dissent 4.3 (1957): $276-93$.

91. See, for example, Monson, Freedom Sounds, Anderson, This Is Our Music; Benjamin Looker, "Point from which Creation Begins": The Black Artists' Group of St. Louis(St. Louis: Missouri Historical Society Press, 2004); Scott Saul, Freedom Is, Freedom Ain't: Jazz and the Making of the Sixties (Cambridge, Mass.: Harvard University Press, 2003). Porter (What Is This Thing Called Jazz:) and Lewis (A Power Stronger than Itself ) both address the intersections of gender, race, and music in a number of different historical contexts, while historian Brian Ward includes several extended discussions of gender politics in R\&B and soul; see Ward, Just My Soul Responding, 71-80, 150-59, and 339-87.

92. See Cedric Robinson, Black Marxism: The Making of the Black Radical Tradition (Chapel Hill: University of North Carolina Press, 1983); and Robin D. G. Kelley, Freedom Dreams: The Black Radical Imagination (Boston: Beacon Press, 2002).

93. See Breines, The Trouble Between Us.

94. A list of musical collectives would include Sun Ra’s Arkestra (Chicago/New York), Horace Tapscott's Union of God's Musicians and Artists Ascension (Los Angeles), the Black Artists' Group (St. Louis), the Detroit Creative Musicians' Association, the Collective Black Artists (New York), and the Creative Music Studio (Woodstock, NY), while closely aligned literary organizations include the Black Arts Repertory Theater and School (New York) and Umbra (New York). Lewis's recent history of the AACM, for example, suggests a different set of valences for thinking through issues of black self-determination; in contrast to the guild, the AACM was an all-black organization that mobilized themes of spirituality, community, and education. Nonetheless, some members recall widespread exscription of women from the organization at various points in its history (Lewis, Power Stronger Than Itself, 200-204, 461, and 477). 